Article

\title{
Effect of Hydrophobicity on the Self-Assembly Behavior of Urea Benzene Derivatives in Aqueous Solution
}

\author{
Yuna Okamoto ${ }^{1}$, Kosuke Morishita ${ }^{1}$, Yasufumi Fuchi ${ }^{2}$, Shigeki Kobayashi ${ }^{2}$ \\ and Satoru Karasawa 2,3,* (D) \\ 1 Graduate School of Pharmaceutical Sciences, Kyushu University, 3-1-1 Maidashi, Higashi-Ku, \\ Fukuoka 812-8582, Japan; yuna.o@abelia.ocn.ne.jp (Y.O.); k.morishita.0917@gmail.com (K.M.) \\ 2 Faculty of Pharmaceutical Sciences, Showa Pharmaceutical University, Machida 194-8543, Japan; \\ fuchi@ac.shoyaku.ac.jp (Y.F.); kobayasi@ac.shoyaku.ac.jp (S.K.) \\ 3 PRESTO, Japan Science and Technology Agency, Kawaguchi 332-0012, Japan \\ * Correspondence: karasawa@ac.shoyaku.ac.jp; Tel.: +81-42-721-1553
}

Received: 10 June 2018; Accepted: 2 July 2018; Published: 3 July 2018

\begin{abstract}
Urea benzene derivatives (UBD) with amphiphilic side chains showed self-assembly behavior in aqueous solution to form nanoparticles $\sim 100 \mathrm{~nm}$ in size. Subsequent thermal treatment led to additional self-assembly of the nanoparticles due to dehydration of the amphiphilic side chains, producing microparticles. This self-assembly process was accompanied by a lower critical solution temperature (LCST) behavior, as revealed by the abrupt decrease in solution transmittance. In this study, three UBD (UBD-1-3) with different lengths of the alkyl segment in the amphiphilic side chain (namely, hexyl, heptyl, and octyl, respectively) were prepared to investigate the self-assembly behavior in aqueous solution. UBD-1-3 formed identical nanoparticles, with sizes in the 10 80 nm range but with different LCST values in the order $3<2<1$. These results suggest a relationship between the hydrophobicity and the self-assembly behavior of UBD.
\end{abstract}

Keywords: nanoparticles; LCST; alkyl urea benzene framework; self-assembly

\section{Introduction}

Biomimetic chemistry can help in the further development of the medical field [1]. Artificial soft materials such as gels and nanoparticles are essential and have been applied in medical and pharmaceutical chemistry. For example, hydrogels [2,3] have been used in artificial joints, corneas, and stents. In addition, functional nanoparticles that can accumulate at a specific target site and release therapeutic agents have become essential tools in drug delivery systems (DDS) [4-6]. Because of their so-called "enhanced permeability and retention (EPR)" effect, that is, the ability to reach the interstitial spaces $(10-500 \mathrm{~nm}$ ) of tumor tissues [7-9], over the past three decades, nanoparticles have emerged as attractive DDS for anticancer drugs. Moreover, the acidic microenvironment of tumor cells, due to the Warburg effect $[10,11]$, facilitates the accumulation of nanoparticles in the target tissue. We have previously reported the self-assembly behavior of urea benzene derivatives (UBD) in aqueous solution to form nanoparticles [12], which can undergo an additional heat-induced self-assembly to produce microparticles. This is accompanied by a lower critical solution temperature (LCST) behavior, resulting in a turbid solution. In addition, UBD have been used in our laboratory for the development of functional materials; namely, radical nanoparticles have been employed for metal-free magnetic resonance imaging contrast agents [13], and push-pull-type, aminoquinoline-based fluorescent probes have been constructed for bioimaging applications [14-18]. Among the latter, we have successfully developed a tumor-imaging probe activated by heat treatment [19]. 
In this study, three UBD (UBD-1-3) with different alkyl chain lengths (hexyl, heptyl, and octyl, respectively) were prepared to investigate the self-assembly behavior in aqueous solution [20,21]. Although nanoparticle formation was observed in all cases, the existence of a critical aggregation concentration (CAC) was indicative of the effect of the alkyl chain length. Herein, we describe the relationship between the self-assembly behavior and the alkyl chain length of UBD-1-3.

\section{Results and Discussion}

\subsection{Synthesis of $U B D-1-3$}

UBD-1-3 contain an amphiphilic chain consisting of hexaethylene glycol and an alkyl chain of different lengths. For the synthesis of the amphiphilic chain, the corresponding dibromoalkane was reacted with hexaethylene glycol monomethyl ether under basic conditions. The resulting chain having a terminal bromine was converted to the phthalimide derivative, which was then reduced to obtain the corresponding amine. This was treated with phenyl isocyanate in toluene to afford the desired UBD, in which the phenyl group and the amphiphilic chain are linked by a urea moiety. The synthetic route to UBD-1-3 is shown in Scheme 1.

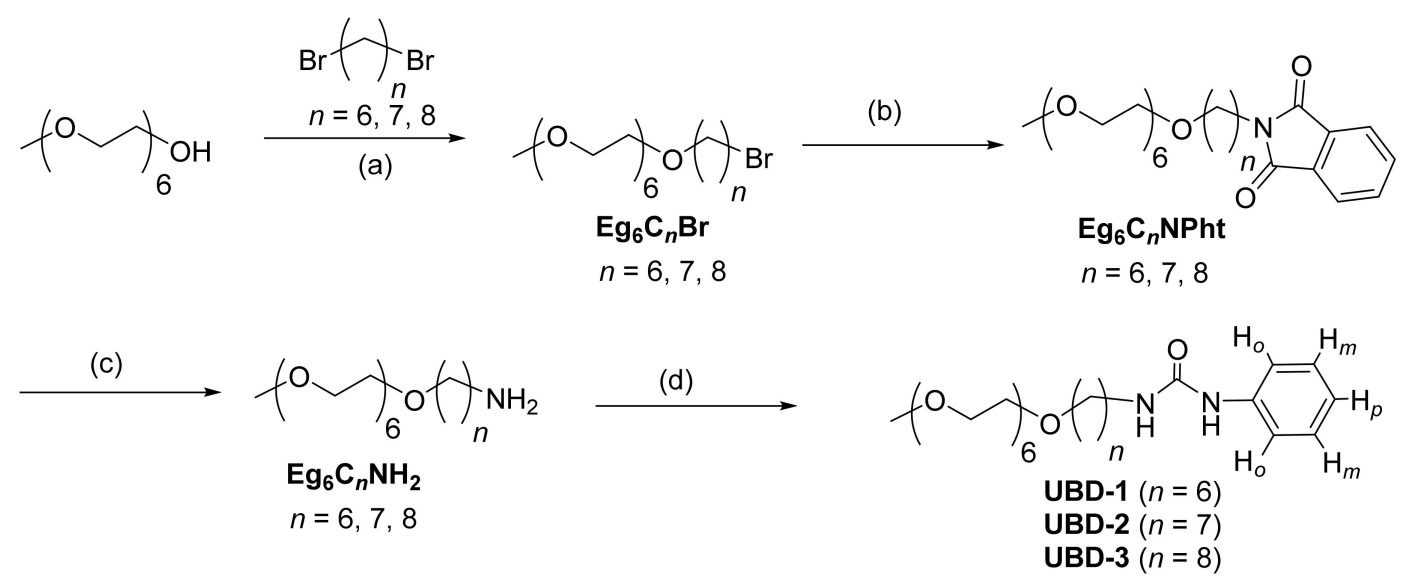

(a) dibromoalkane, $\mathrm{NaH}, \mathrm{THF}$; (b) potassium pththalimide, DMF; (c) hydrazine monohydrate, EtOH;

(d) phenyl isocyanate

Scheme 1. Synthetic route to UBD-1-3.

\subsection{Self-Assembly Behavior in Aqueous Solution}

\subsection{1. ${ }^{1} \mathrm{H}$ NMR spectra in $\mathrm{D}_{2} \mathrm{O}$}

The prepared UBD-1-3 underwent self-assembly in aqueous solution to form aggregates. To determine the critical aggregation concentrations (CACs), the concentration dependence of the ${ }^{1} \mathrm{H} N M R$ spectra in $\mathrm{D}_{2} \mathrm{O}$ was investigated, and the spectral changes for UBD-1 having a hexyl chain are shown in Figure 1a,b.

The signals corresponding to the alkyl, ethylene glycol, and phenyl moieties were observed in the ranges of 1.1-1.6, 3.0-3.7, and 6.9-7.5 ppm, respectively. For concentrations between 0.25 and $20 \mathrm{mM}$, no chemical shift changes were observed, indicating that UBD-1 was in the monomeric form in this concentration range. Above $20 \mathrm{mM}$, the proton peaks of the alkyl and ethylene glycol chains as well as some phenyl signals shifted to higher shielding and broadened, suggesting a concentration dependence. In contrast, the aromatic protons in the ortho position $\left(\mathrm{H}_{o}\right.$ in Scheme 1$)$ were deshielded. These shielding $[13,19,22]$ and deshielding shifts $[13,19,23]$ typically derive from the formation of aggregates and the interaction via hydrogen bond between urea moiety and $\mathrm{H}_{o}$ atoms in the phenyl ring, respectively. The chemical shift of the aromatic protons in the meta position 
( $\mathrm{H}_{m}$ in Scheme 1) was plotted as a function of the concentration, and a breaking point was observed at $16 \mathrm{mM}$ (Figure 1c), which corresponds to the CAC of UBD-1. Notably, compared to UBD-1, UBD-2 and -3 with heptyl and octyl chains, respectively (Figure S1), showed a similar concentration dependence but different CAC values ( 9.0 and $2.0 \mathrm{mM}$, respectively), indicating that the CAC depended on the hydrophobicity of the amphiphilic chain. As expected, a longer chain was associated with a smaller CAC value. For all UBD, the ${ }^{1} \mathrm{H}$ NMR spectral changes with concentration are shown in Figure 1 and Figure S1, and the chemical shift changes of the meta protons are shown in Figure 1c. Moreover, the CAC and LCST values are summarized in Table 1.
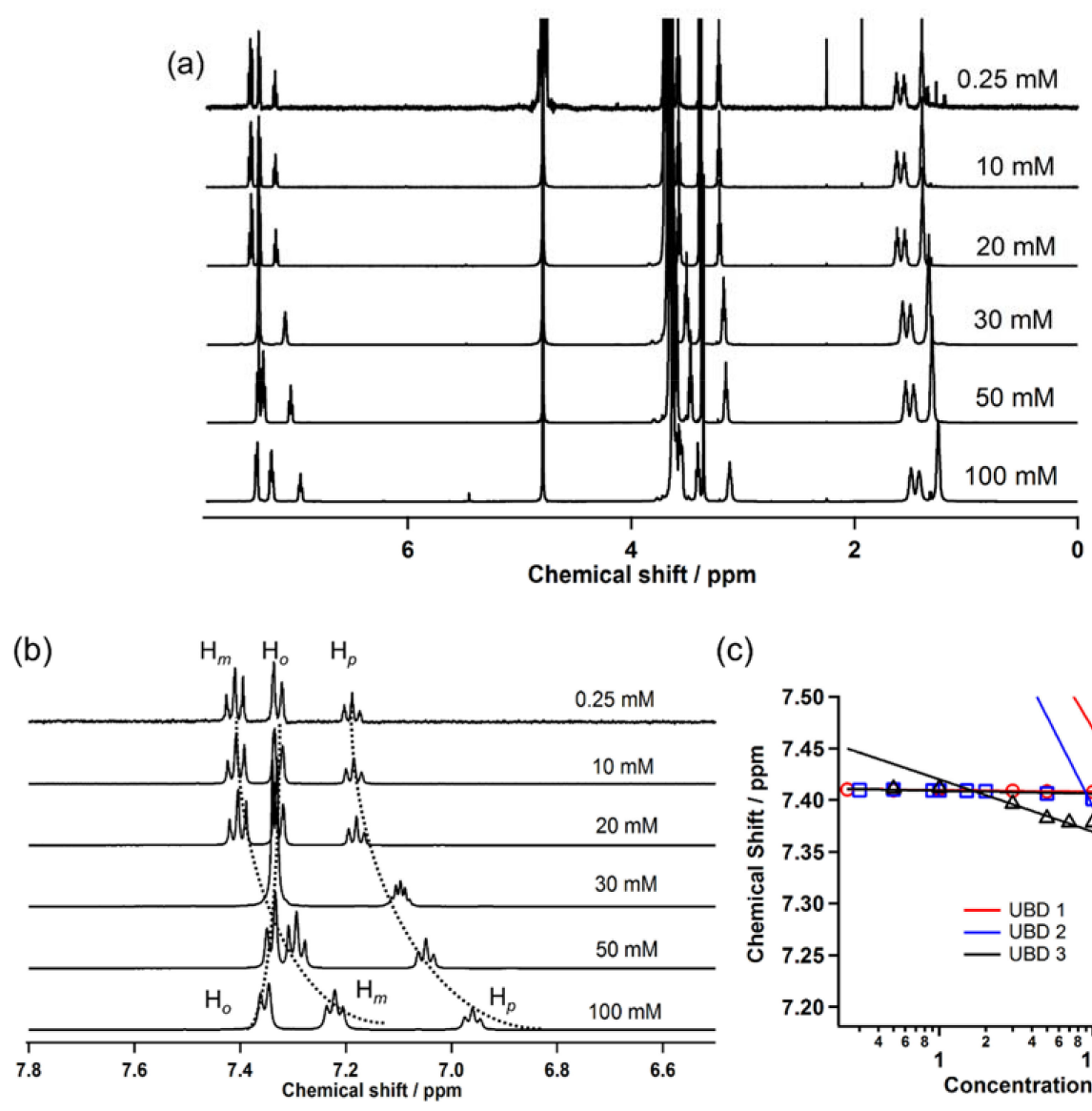

(c)

Figure 1. ${ }^{1} \mathrm{H}$ NMR spectral changes with concentration of UBD-1. (a) ${ }^{1} \mathrm{H}$ NMR spectra in the chemical shift region of 0.0-7.8 ppm; and (b) enlarged aromatic region; (c) Plots of the $\mathrm{H}_{m}$ chemical shift as a function of the concentration for UBD-1-3. $\mathrm{H}_{m}$ indicates the aromatic protons in the meta position (Scheme 1).

2.2.2. Size Distribution and Morphology of UBD-1-3 by Dynamic Light Scattering (DLS) and Transmission Electron Microscopy (TEM)

The size distribution and morphology of the resulting UBD-1-3 aggregates in aqueous solution were determined by DLS and TEM. The DLS spectrum of a $20 \mathrm{mM}$ UBD-1 solution at $20{ }^{\circ} \mathrm{C}$ showed a broad peak corresponding to a hydrodynamic diameter $\left(D_{\mathrm{H}}\right)$ of approximately $30 \mathrm{~nm}$ (Figure $2 \mathrm{a}$ ). At $90{ }^{\circ} \mathrm{C}$, the peak shifted to about $200 \mathrm{~nm}$, indicating that the aggregate size $\left(D_{\mathrm{H}}\right.$ value) was temperature dependent, increasing with increasing temperature. The temperature dependence of the $D_{\mathrm{H}}$ values for UBD-1 is illustrated in Figure S2, which also shows the transmittance changes (vide infra). A similar temperature dependence of the size distribution was observed for UBD-2 and -3 aggregates $(10 \mathrm{mM})$. At $20^{\circ} \mathrm{C}$, UBD-2 and -3 had a size of approximately $20 \mathrm{~nm}$ and $70 \mathrm{~nm}$, respectively, and at $30^{\circ} \mathrm{C}$, the $D_{\mathrm{H}}$ values shifted to larger sizes, namely, $\sim 1500$ and $\sim 4000 \mathrm{~nm}$, respectively (Figure 2b). 
The temperature-dependent change in size distribution for UBD-1 is shown in Figure 2a, and for all UBD, the temperature dependence of $D_{\mathrm{H}}$ is shown in Figure 2c.

(a)

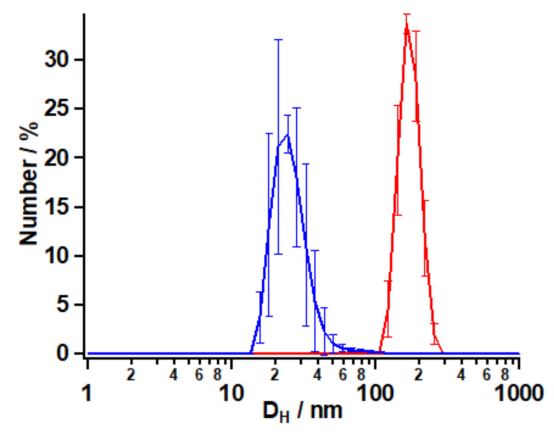

(b)

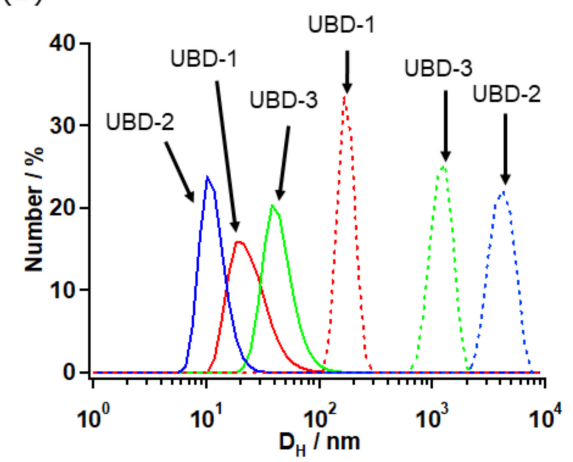

Figure 2. (a) Size distribution of $20 \mathrm{mM}$ UBD-1 solution at 20 (blue line) and $90{ }^{\circ} \mathrm{C}$ (red line); (b) Size distribution of $10 \mathrm{mM}$ UBD-1 (red lines), $10 \mathrm{mM}$ UBD-2 (blue lines), and $10 \mathrm{mM}$ UBD-3 (green lines) solutions, below (solid lines) and above (dotted lines) the cloud point.

The TEM images of UBD were obtained using uranyl acetate as a negative staining agent and the dried samples prepared according to previous reports $[12,13,19]$. As can be seen from the images shown in Figure 3, for all UBD, spherical nanoparticles with sizes in the 10-80 nm range were observed. The size difference between DLS and TEM measurements could be attributed to the presence or absence of water molecules in the nanoparticles, indicating that UBD-1-3 formed spherical nanoparticles $10-80 \mathrm{~nm}$ in size in aqueous solution. The TEM images of all UBD are shown in Figure 3.
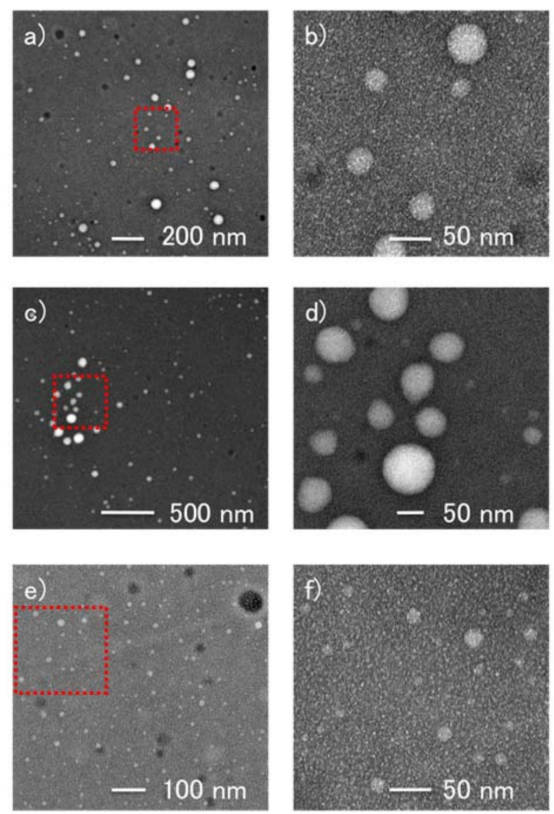

Figure 3. TEM images of UBD-1 $(\mathbf{a}, \mathbf{b}),-\mathbf{2}(\mathbf{c}, \mathbf{d})$, and $\mathbf{- 3}(\mathbf{e}, \mathbf{f})$. The right panels $(\mathbf{b}, \mathbf{d}, \mathbf{f})$ show enlarged images of the red dotted squares in left panels.

\subsubsection{Additional Heat-Induced Self-Assembly}

The hexaethylene glycol chain of UBD formed hydrogen bonds with water molecules and can undergo dehydration by thermal treatment, resulting in an entropy-driven self-assembly process [24,25]. To examine this heat-induced self-assembly behavior of the nanoparticles, the temperature dependence 
of the transmittance was measured. For 10, 15, and $20 \mathrm{mM}$ solutions of UBD-1, an abrupt decrease in transmittance was detected, with LCST at 71,51 , and $38{ }^{\circ} \mathrm{C}$, respectively. On the other hand, at concentrations below $10 \mathrm{mM}$, the transmittance decreased gradually (Figure 4a). It should be noted that similar LCST behavior and concentration dependence were observed for UBD-2 and -3. Namely, in the case of 5, 10, and $20 \mathrm{mM}$ solutions of UBD-2, the LCSTs were found at 57, 29, and $26^{\circ} \mathrm{C}$, whereas for 3,7 , and $10 \mathrm{mM}$ solutions of UBD-3, LCSTs at 27,23 , and $23^{\circ} \mathrm{C}$ were observed. At a specific concentration (10 mM) of UBD-1-3, the LCSTs followed the order UBD-3 $<\mathbf{2}<\mathbf{1}$, indicating that longer alkyl chains provide lower cloud points [26,27] due to hydrophobic effects (Figure 4b). The LCST behavior of UBD is shown in Figure 4 and Figure S3, and the LCST values are summarized in Table 1.
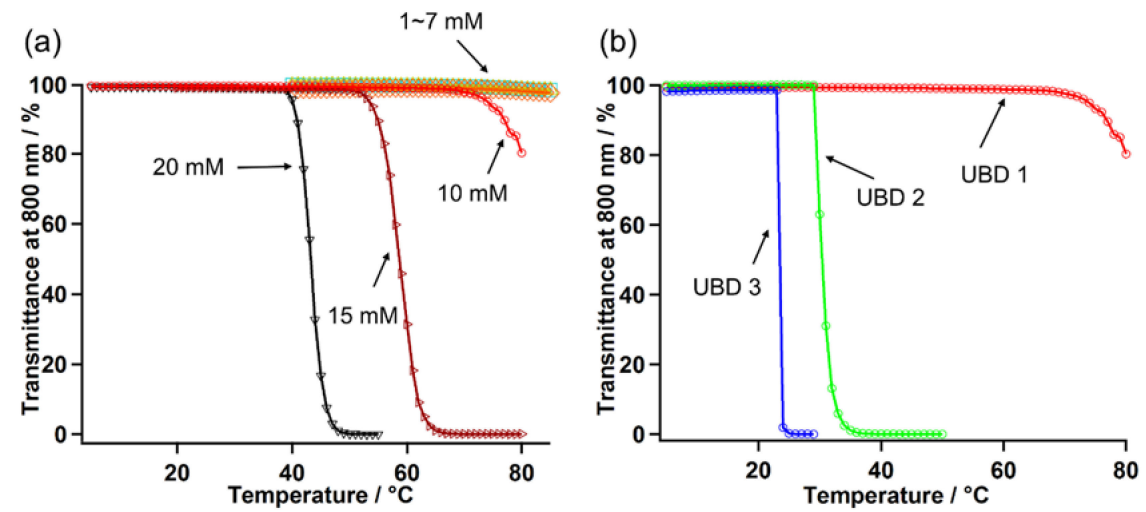

Figure 4. LCST behavior of (a) UBD-1 at given concentrations and (b) $10 \mathrm{mM}$ solutions of UBD-1-3.

Table 1. CAC Values and Concentration Dependence of the LCST Values of UBD.

\begin{tabular}{|c|c|c|c|}
\hline & UBD-1 & UBD-2 & UBD-3 \\
\hline & \multicolumn{3}{|c|}{ CAC } \\
\hline & $16 \mathrm{mM}$ & $9 \mathrm{mM}$ & $2 \mathrm{mM}$ \\
\hline Concentration/mM & & LCST & \\
\hline 20 & $38^{\circ} \mathrm{C}$ & $26^{\circ} \mathrm{C}$ & - \\
\hline 15 & $51^{\circ} \mathrm{C}$ & - & $23{ }^{\circ} \mathrm{C}$ \\
\hline 10 & $71^{\circ} \mathrm{C}$ & $29^{\circ} \mathrm{C}$ & - \\
\hline 7 & $>80^{\circ} \mathrm{C}$ & - & $23^{\circ} \mathrm{C}$ \\
\hline 5 & $>80^{\circ} \mathrm{C}$ & $57^{\circ} \mathrm{C}$ & - \\
\hline 3 & - & $>80^{\circ} \mathrm{C}$ & $27^{\circ} \mathrm{C}$ \\
\hline 1 & $>80^{\circ} \mathrm{C}$ & - & - \\
\hline
\end{tabular}

\section{Materials and Methods}

\subsection{Experimental}

Instruments: Infrared spectra for freeze-dry samples of UBD-1, -2, and $\mathbf{- 3}$ were recorded on a JASCO 420 FT-IR spectrometer (Figure S4) $[28,29]$. UV-Vis spectra were recorded on a JASCO V570 spectrometer equipped with a JASCO 420 temperature controller. ${ }^{1} \mathrm{H}$ and ${ }^{13} \mathrm{C}$ NMR spectra were measured on a Bruker Biospin AVANCE III 500 spectrometer or a Varian 500 Fourier transform NMR spectrometer using $\mathrm{CDCl}_{3}, \mathrm{CD}_{3} \mathrm{OD}$, or $\mathrm{D}_{2} \mathrm{O}$ as a solvent and referenced to tetramethylsilane or 4,4-dimethyl-4-silapentane-1-sulfonic acid. DLS measurements were performed with a Malvern Zetasizer Nano ZS instrument with a helium-neon laser (wavelength: $633 \mathrm{~nm}$ ) at a scattering angle of $173^{\circ}$. High-resolution electrospray ionization mass spectra were recorded using a Bruker Daltonics microTOF mass spectrometer. TEM images were obtained using a FEI Tecnai F20 transmission electron microscope operating at $200 \mathrm{kV}$. Samples for TEM observations were prepared by dropping the UBD solutions on a carbon-coated copper grid, followed by staining with uranyl acetate, and drying 
at room temperature. The LCST behavior of the UBD solutions was investigated by monitoring the change in the cloud point, which was determined by the inflection point of the transmittance at $800 \mathrm{~nm}$ as a function of temperature. The temperature of the sample in a cuvette was set at $10^{\circ} \mathrm{C}$ and increased by increments of $1{ }^{\circ} \mathrm{C}$ up to a final temperature of $85^{\circ} \mathrm{C}$. Each measurement was obtained after maintaining the temperature for $120 \mathrm{~s}$. Elemental analyses were performed using a Perkin Elmer 2400 II analyzer at the Center for Industry, University and Government Cooperation, Nagasaki University.

\subsection{Materials}

26-bromo-2,5,8,11,14,17,20-heptaoxahexacosane $\left(\mathrm{Eg}_{6} \mathrm{C}_{6} \mathrm{Br}\right)$

To a solution of 1,6-dibromohexane $(5.93 \mathrm{~mL}, 39.1 \mathrm{mmol})$ and $60 \%$ sodium hydride $(0.939 \mathrm{~g}$, $23.5 \mathrm{mmol}$ ) in $8.5 \mathrm{~mL}$ THF was added dropwise to a solution of hexaethylene glycol monomethyl ether $(2.32 \mathrm{~g}, 7.83 \mathrm{mmol})$ in $8.5 \mathrm{~mL}$ THF while stirring in an ice bath, and the mixture was stirred overnight at room temperature. The resulting solution was diluted with a mixture of $\mathrm{MeOH}$ and saturated ammonium chloride aqueous solution and then extracted three times with $\mathrm{Et}_{2} \mathrm{O}$. The combined organic phases were dried over $\mathrm{MgSO}_{4}$ and evaporated. The resulting residue was chromatographed on silica gel with n-hexane/AcOEt (100:5-100:30) as the eluent to afford $\mathbf{E g}_{6} \mathbf{C}_{6} \mathbf{B r}$ as a colorless oil in $81.9 \%$ yield $(2.95 \mathrm{~g}, 6.42 \mathrm{mmol}) .{ }^{1} \mathrm{H} \mathrm{NMR}\left(\mathrm{CDCl}_{3}, 270 \mathrm{MHz}\right) \delta 3.63-3.26(m, 24 \mathrm{H}), 3.59-3.53(\mathrm{~m}, 2 \mathrm{H}), 3.46$ $(t, J=6.8 \mathrm{~Hz}, 2 \mathrm{H}), 3.38(\mathrm{~s}, 3 \mathrm{H}), 1.89-1.81(m, 2 \mathrm{H}), 1.62-1.57(m, 2 \mathrm{H}), 1.40-1.36(m, 4 \mathrm{H})$. The ${ }^{1} \mathrm{H}$ NMR spectrum was consistent with that previously reported [19].

27-bromo-2,5,8,11,14,17,20-heptaoxaheptacosane $\left(\mathrm{Eg}_{6} \mathrm{C}_{7} \mathrm{Br}\right)$

$\mathrm{Eg}_{6} \mathrm{C}_{7} \mathrm{Br}$ was prepared in a manner similar to that described for $\mathrm{Eg}_{6} \mathrm{C}_{6} \mathrm{Br}$, using dibromoheptane instead of dibromohexane. The reaction yield was $66.4 \% .{ }^{1} \mathrm{H} \mathrm{NMR}\left(\mathrm{CDCl}_{3}, 500 \mathrm{MHz}\right) \delta 3.53-3.49$ $(m, 22 \mathrm{H}), 3.47-3.46(m, 2 \mathrm{H}), 3.44-3.42(m, 2 \mathrm{H}), 3.38(t, J=2.5 \mathrm{~Hz}, 2 \mathrm{H}), 3.23(s, 3 \mathrm{H}), 1.49-1.46(m, 2 \mathrm{H})$, $1.37-1.36(m, 2 \mathrm{H}), 1.30-1.27(m, 6 \mathrm{H})$. HRMS (ESI) Calcd. for $\mathrm{C}_{20} \mathrm{H}_{41} \mathrm{BrNaO}_{7}[\mathrm{M}+\mathrm{Na}]^{+}: m / z$ 495.1833, Found: 475.1819 .

28-bromo-2,5,8,11,14,17,20-heptaoxaoctacosane $\left(\mathrm{Eg}_{6} \mathrm{C}_{8} \mathrm{Br}\right)$

$\mathrm{Eg}_{6} \mathrm{C}_{8} \mathrm{Br}$ was prepared in a manner similar to that described for $\mathrm{Eg}_{6} \mathrm{C}_{6} \mathrm{Br}$, using dibromooctane instead of dibromohexane. The reaction yield was $67.7 \% .{ }^{1} \mathrm{H}$ NMR $\left(\mathrm{CDCl}_{3}, 500 \mathrm{MHz}\right) \delta 3.65-3.64$ $(m, 20 \mathrm{H}), 3.58-3.54(m, 4 \mathrm{H}), 3.46-3.39(m, 4 \mathrm{H}), 3.38(\mathrm{~s}, 3 \mathrm{H}), 1.88-1.82(m, 2 \mathrm{H}), 1.60-1.54(m, 2 \mathrm{H}), 1.46-1.38$ $(s, 2 \mathrm{H}), 1.31(m, 6 \mathrm{H})$. HRMS (ESI) Calcd. for $\mathrm{C}_{21} \mathrm{H}_{43} \mathrm{BrNaO}_{7}[\mathrm{M}+\mathrm{Na}]^{+}: m / z$ 509.2090, Found: 509.2046.

2-(2,5,8,11,14,17,20-heptaoxahexacosan-26-yl)isoindoline-1,3-dione ( $\left.\mathrm{Eg}_{6} \mathrm{C}_{6} \mathrm{NPht}\right)$

A mixture of $\mathbf{E g}_{6} \mathbf{C}_{6} \mathbf{B r}(2.94 \mathrm{~g}, 6.40 \mathrm{mmol})$ and potassium phthalimide $(1.30 \mathrm{~g}, 7.04 \mathrm{mmol})$ in $49.3 \mathrm{~mL}$ DMF was stirred at $110^{\circ} \mathrm{C}$ for $4 \mathrm{~h}$. After cooling to room temperature, the resulting solution was evaporated and diluted with water. The obtained mixture was extracted three times with $\mathrm{Et}_{2} \mathrm{O}$ and the combined organic phases were dried over $\mathrm{MgSO}_{4}$ and evaporated to afford $\mathbf{E g}_{6} \mathbf{C}_{6} \mathbf{N P h t}$ as a colorless oil in 73.5\% yield ( $2.47 \mathrm{~g}$, $4.70 \mathrm{mmol})$. IR (Neat on $\mathrm{NaCl}) 3465,2932,2862,1716,1606,1459$, 1399, 1360, 1302, 1251, 1104, $721 \mathrm{~cm}^{-1} .{ }^{1} \mathrm{H}$ NMR $\left(\mathrm{CDCl}_{3}, 270 \mathrm{MHz}\right) \delta 7.86-7.83(\mathrm{~m}, 2 \mathrm{H}), 7.72-7.69$ $(m, 2 \mathrm{H}), 3.70-3.61(m, 20 \mathrm{H}), 3.58-3.53(m, 4 \mathrm{H}), 3.46-3.41(t, J=6.75 \mathrm{~Hz}, 2 \mathrm{H}), 3.38(s, 3 \mathrm{H}), 1.70-1.65$ $(m, 4 \mathrm{H}), 1.59(m, 2 \mathrm{H}), 1.38-1.36(m, 4 \mathrm{H})$. The ${ }^{1} \mathrm{H}$ NMR spectrum was consistent with that previously reported [19].

\section{2-(2,5,8,11,14,17,20-heptaoxaheptacosan-27-yl)isoindoline-1,3-dione ( $\left.\mathrm{Eg}_{6} \mathrm{C}_{7} \mathrm{NPht}\right)$}

$\mathrm{Eg}_{6} \mathrm{C}_{7} \mathrm{NPht}$ was prepared in a manner similar to that described for $\mathrm{Eg}_{6} \mathrm{C}_{6} \mathrm{NPht}$, using $\mathrm{Eg}_{6} \mathrm{C}_{7} \mathrm{Br}$ instead of $\mathbf{E g}_{6} \mathbf{C}_{6} \mathbf{B r}$. The reaction yield was $76.7 \%$. IR (neat on $\mathrm{NaCl}$ ) 3517, 2930, 2863, 1771, 1713, $1635,1467,1438,1396,1369,1108,722 \mathrm{~cm}^{-1} .{ }^{1} \mathrm{H}$ NMR $\left(\mathrm{CDCl}_{3}, 500 \mathrm{MHz}\right) \delta 7.85-7.83(d d, J=5.45$, $3.05 \mathrm{~Hz}, 2 \mathrm{H}), 7.71-7.70(d d, J=5.45,3.00 \mathrm{~Hz}, 2 \mathrm{H}), 3.69-3.62(m, 20 \mathrm{H}), 3.57-3.54(m, 4 \mathrm{H}), 3.44-3.42$ 
$(t, J=6.78 \mathrm{~Hz}, 2 \mathrm{H}), 3.38(\mathrm{~s}, 3 \mathrm{H}), 1.70-1.64(m, 4 \mathrm{H}), 1.59-1.54(m, 2 \mathrm{H}), 1.34-1.30(m, 6 \mathrm{H})$. HRMS (ESI) Calcd. for $\mathrm{C}_{28} \mathrm{H}_{45} \mathrm{NNaO}_{9}[\mathrm{M}+\mathrm{Na}]^{+}: \mathrm{m} / z$ 562.2992, Found: 562.3199 .

2-(2,5,8,11,14,17,20-heptaoxaoctacosan-28-yl)isoindoline-1,3-dione ( $\left.\mathrm{Eg}_{6} \mathrm{C}_{8} \mathrm{NPht}\right)$

$\mathrm{Eg}_{6} \mathrm{C}_{8} \mathrm{NPht}$ was prepared in a manner similar to that described for $\mathrm{Eg}_{6} \mathrm{C}_{6} \mathrm{NPht}$, using $\mathrm{Eg}_{6} \mathrm{C}_{8} \mathrm{Br}$ instead of $\mathbf{E g}_{6} \mathrm{C}_{6} \mathbf{B r}$. The reaction yield was $94.7 \%$. ${ }^{1} \mathrm{H}$ NMR $\left(\mathrm{CDCl}_{3}, 500 \mathrm{MHz}\right) \delta 7.85-7.83(d d, J=5.45$, $3.05 \mathrm{~Hz}, 2 \mathrm{H}), 7.71-7.70(d d, J=5.4,3.00 \mathrm{~Hz}, 2 \mathrm{H}), 3.68-3.62(m, 20 \mathrm{H}), 3.58-3.54(m, 4 \mathrm{H}), 3.44-3.42(t$, $J=6.85 \mathrm{~Hz}, 2 \mathrm{H}), 3.38(\mathrm{~s}, 3 \mathrm{H}), 1.68-1.64(m, 2 \mathrm{H}), 1.58-1.53(m, 2 \mathrm{H}), 1.33-1.30(m, 10 \mathrm{H})$. HRMS (ESI) Calcd. for $\mathrm{C}_{29} \mathrm{H}_{47} \mathrm{NNaO}_{9}[\mathrm{M}+\mathrm{Na}]^{+}: m / z 576.3149$, Found: 576.3349 .

2,5,8,11,14,17,20-heptaoxahexacosan-26-amine $\left(\mathrm{Eg}_{6} \mathrm{C}_{6} \mathrm{NH}_{2}\right)$

To a solution of $\mathbf{E g}_{6} \mathbf{C}_{6} \mathbf{N P h t}(4.69 \mathrm{~g}, 8.92 \mathrm{mmol})$ in $40 \mathrm{~mL}$ EtOH, hydrazine monohydrate $(1.73 \mathrm{~mL}$, $35.7 \mathrm{mmol}$ ) was added dropwise, and the mixture was refluxed for $2 \mathrm{~h}$. The resulting solution was cooled to room temperature and evaporated to afford a white solid. The residue was dissolved with $\mathrm{Et}_{2} \mathrm{O}$ and filtered over Celite. After evaporation of the filtrate, the residue was chromatographed on silica gel with $\mathrm{CH}_{2} \mathrm{Cl}_{2} / \mathrm{MeOH} /$ trimethylamine (1:0.02:0.05) as the eluent to afford $\mathbf{E g}_{6} \mathbf{C}_{\mathbf{6}} \mathbf{N H}_{\mathbf{2}}$ as a pale yellow transparent oil in $97.8 \%$ yield $(3.57 \mathrm{~g}, 9.03 \mathrm{mmol}$ ). IR (neat on $\mathrm{NaCl}) 3429,2933,2862$, 1646, 1567, 1461, 1352, 1246, 1105, 938, $847 \mathrm{~cm}^{-1} .{ }^{1} \mathrm{H}$ NMR $\left(\mathrm{CDCl}_{3}, 270 \mathrm{MHz}\right) \delta 3.66-3.62(\mathrm{~m}, 20 \mathrm{H})$, $3.59-3.53(m, 4 \mathrm{H}), 3.45(t, J=8.1 \mathrm{~Hz}, 2 \mathrm{H}), 3.38(\mathrm{~s}, 3 \mathrm{H}), 2.71(t, J=6.75 \mathrm{~Hz}, 2 \mathrm{H}), 1.74(m, 2 \mathrm{H}), 1.59-1.56$ $(t, J=4.05 \mathrm{~Hz}, 2 \mathrm{H}), 1.45-1.25(m, 6 \mathrm{H})$. HRMS (ESI) Calcd. for $\mathrm{C}_{19} \mathrm{H}_{42} \mathrm{NO}_{7}[\mathrm{M}+\mathrm{H}]^{+}: m / z$ 396.2961, Found: 396.3093 .

2,5,8,11,14,17,20-heptaoxaheptacosan-27-amine $\left(\mathrm{Eg}_{6} \mathrm{C}_{7} \mathrm{NH}_{2}\right)$

$\mathrm{Eg}_{6} \mathrm{C}_{7} \mathbf{N H}_{2}$ was prepared in a manner similar to that described for $\mathbf{E g}_{6} \mathrm{C}_{6} \mathbf{N H}_{2}$, using $\mathbf{E g}_{6} \mathrm{C}_{7} \mathbf{N P h t}$ instead of $\mathbf{E g}_{6} \mathrm{C}_{6} \mathbf{N P h t}$. The reaction yield was $86.2 \%$. ${ }^{1} \mathrm{H}$ NMR (DMSO- $d_{6}, 270 \mathrm{MHz}$ ) $\delta 3.53-3.50$ $(m, 24 \mathrm{H}), 3.49-3.30(m, 2 \mathrm{H}), 3.37(s, 3 \mathrm{H}), 2.71-2.69(t, J=5.0 \mathrm{~Hz}, 2 \mathrm{H}), 1.74(m, 4 \mathrm{H}), 1.50-1.45(t$, $J=12.5 \mathrm{~Hz}, 2 \mathrm{H}), 1.40-1.30(m, 4 \mathrm{H}), 1.19-1.13(m, 2 \mathrm{H})$. HRMS (ESI) Calcd. for $\mathrm{C}_{20} \mathrm{H}_{44} \mathrm{NO}_{7}[\mathrm{M}+\mathrm{H}]^{+}$: $m / z$ 410.3118, Found: 410.2994 .

\section{2,5,8,11,14,17,20-heptaoxaoctacosan-28-amine $\left(\mathrm{Eg}_{6} \mathrm{C}_{8} \mathrm{NH}_{2}\right)$}

$\mathrm{Eg}_{6} \mathrm{C}_{8} \mathbf{N H}_{2}$ was prepared in a manner similar to that described for $\mathbf{E g}_{6} \mathrm{C}_{6} \mathbf{N H}_{2}$, using $\mathbf{E g}_{6} \mathrm{C}_{8} \mathbf{N P h t}$ instead of $\mathbf{E g}_{6} \mathbf{C}_{6} \mathbf{N P h t}$. The reaction yield was $81.8 \%$. ${ }^{1} \mathrm{H}$ NMR (DMSO- $\left.d_{6}, 500 \mathrm{MHz}\right) \delta 3.51-3.50$ $(m, 16 \mathrm{H}), 3.47-3.45(m, 2 \mathrm{H}), 3.45-3.41(m, 2 \mathrm{H}), 3.40-3.23(m, 6 \mathrm{H}), 3.24(s, 3 \mathrm{H}), 2.60-2.56(t, J=10 \mathrm{~Hz}, 2 \mathrm{H})$, $1.49-1.46(m, 2 \mathrm{H}), 1.40-1.36(m, 2 \mathrm{H}), 1.30-1.20(m, 6 \mathrm{H})$. HRMS (ESI) Calcd. for $\mathrm{C}_{21} \mathrm{H}_{46} \mathrm{NO}_{7}[\mathrm{M}+\mathrm{H}]^{+}$: $m / z$ 424.3274, Found: 424.3145 .

\section{1-(2,5,8,11,14,17,20-heptaoxahexacosan-26-yl)-3-phenylurea (UBD-1)}

To a solution of phenyl isocyanate ( $52.9 \mathrm{mg}, 0.44 \mathrm{mmol}$ ) in $1 \mathrm{~mL}$ toluene, a solution of $\mathbf{E g}_{6} \mathbf{C}_{6} \mathbf{N H}_{2}$

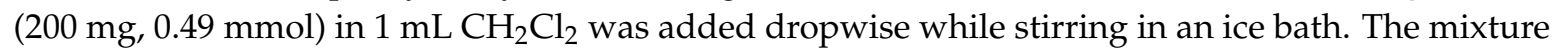
was stirred overnight, allowing it to reach room temperature. The resulting solution was evaporated and chromatographed on silica gel with $\mathrm{CH}_{2} \mathrm{Cl}_{2} / \mathrm{MeOH}$ (10:1) as the eluent to afford $189 \mathrm{mg}$ of mono-PhC6 as a colorless oil in $82.6 \%$ yield. IR (neat on $\mathrm{NaCl}$ ) 3348, 2931, 2864, 1696, 1668, 1597, $1553,1500,1441,1350,1311,1238,1109,949,850 \mathrm{~cm}^{-1} .{ }^{1} \mathrm{H}$ NMR (DMSO- $\left.d_{6}, 500 \mathrm{MHz}\right) \delta 8.35(s, 1 \mathrm{H})$, 7.38-7.37 $(d d, J=8.7,1.2 \mathrm{~Hz}, 2 \mathrm{H}), 7.21-7.18(t, J=8.0 \mathrm{~Hz}, 2 \mathrm{H}), 6.89-6.85(t, J=8.5 \mathrm{~Hz}, 1 \mathrm{H}), 6.09-6.07(t$, $J=5.6 \mathrm{~Hz}, 1 \mathrm{H}), 3.50-3.49(m, 20 \mathrm{H}), 3.46-3.45(m, 2 \mathrm{H}), 3.43-3.41(m, 2 \mathrm{H}), 3.39-3.36(t, J=6.6 \mathrm{~Hz}, 2 \mathrm{H})$, $3.23(s, 3 \mathrm{H}), 3.08-3.03(q, J=12.7,6.9 \mathrm{~Hz}, 2 \mathrm{H}), 1.51-1.48(m, 2 \mathrm{H}), 1.43-1.40(m, 2 \mathrm{H}), 1.30-1.29(m, 4 \mathrm{H})$. ${ }^{13} \mathrm{C}$ NMR (DMSO- $\left.d_{6}, 126 \mathrm{MHz}\right) \delta 155.21,140.61,128.62,120.90,117.56,71.29,70.29,69.81,69.60,69.50$, $58.06,39.52,29.76,29.21,26.25,25.45$. HRMS (ESI) Calcd. for $\mathrm{C}_{26} \mathrm{H}_{46} \mathrm{~N}_{2} \mathrm{NaO}_{8}[\mathrm{M}+\mathrm{Na}]^{+}: \mathrm{m} / z$ 537.3152, Found: 537.3259 . 
1-(2,5,8,11,14,17,20-heptaoxaheptacosan-27-yl)-3-phenylurea (UBD-2)

UBD-2 was prepared in a manner similar to that described for mono-PhC6, using $\mathbf{E g}_{6} \mathbf{C}_{7} \mathbf{N H}_{2}$ instead of $\mathbf{E g}_{\mathbf{6}} \mathbf{C}_{\mathbf{6}} \mathbf{N H}_{\mathbf{2}}$. The reaction yield was $91.5 \%$. IR (neat on $\mathrm{NaCl}$ ) 3306, 2929, 2864, 1686, 1597, 1551, 1500, 1442, 1351, 1313, 1239, 1106, 952, $849 \mathrm{~cm}^{-1} .{ }^{1} \mathrm{H}$ NMR (DMSO- $\left.d_{6}, 500 \mathrm{MHz}\right) \delta 8.36(s, 1 \mathrm{H})$, 7.37-7.35 (dd, $J=8.7,1.2 \mathrm{~Hz}, 2 \mathrm{H}), 7.20-7.18(t, J=4.3 \mathrm{~Hz}, 2 \mathrm{H}), 6.87-6.86(t, J=1.0 \mathrm{~Hz}, 1 \mathrm{H}), 6.10-6.08$ $(t, J=5.6 \mathrm{~Hz}, 1 \mathrm{H}), 3.50-3.49(m, 24 \mathrm{H}), 3.47-3.45(m, 2 \mathrm{H}), 3.43-3.41(m, 2 \mathrm{H}), 3.38-3.34(t, J=10.3 \mathrm{~Hz}$, $2 \mathrm{H}), 3.23(\mathrm{~s}, 3 \mathrm{H}), 3.08-3.04(q, J=12.7,6.8 \mathrm{~Hz}, 2 \mathrm{H}), 1.50-1.47(m, 2 \mathrm{H}), 1.43-1.40(m, 2 \mathrm{H}), 1.28(m, 6 \mathrm{H})$. ${ }^{13} \mathrm{C}$ NMR (DMSO, $\left.126 \mathrm{MHz}\right) \delta 155.23,140.60,128.64,120.93,117.58,71.29,70.32,69.81,69.60,69.50$, 58.07, 39.25, 29.72, 29.17, 28.61, 26.37, 25.66. HRMS (ESI) Calcd. for $\mathrm{C}_{27} \mathrm{H}_{48} \mathrm{~N}_{2} \mathrm{NaO}_{8}[\mathrm{M}+\mathrm{Na}]^{+}$: $m / z$ 537.3308, Found: 551.3323. Anal. Calcd. for $\mathrm{C}_{27} \mathrm{H}_{48} \mathrm{~N}_{2} \mathrm{O}_{8}$ : C, 61.34; $\mathrm{H}, 9.15 ; \mathrm{N}, 5.30$, Found: $\mathrm{C}, 61.33$; $\mathrm{H}, 9.26 ; \mathrm{N}, 5.44$.

1-(2,5,8,11,14,17,20-heptaoxaoctacosan-28-yl)-3-phenylurea (UBD-3)

UBD-3 was prepared in a manner similar to that described for mono-PhC6, using $\mathbf{E g}_{6} \mathbf{C}_{8} \mathbf{N H}_{\mathbf{2}}$ instead of $\mathbf{E g}_{6} \mathbf{C}_{6} \mathbf{N H}_{\mathbf{2}}$. The reaction yield was $45.6 \%$. IR (neat on $\mathrm{KBr}$ ) 3303, 2927, 2860, 1685, 1597, $1551,1450,1441,1351,1312,1236,1106,951,849 \mathrm{~cm}^{-1} .{ }^{1} \mathrm{H}$ NMR (DMSO- $\left.d_{6}, 500 \mathrm{MHz}\right) \delta 8.35(s, 1 \mathrm{H})$, $7.37-7.35(d d, J=8.6,1.0 \mathrm{~Hz}, 2 \mathrm{H}), 7.21-7.18(t, J=7.9 \mathrm{~Hz}, 2 \mathrm{H}), 6.88-6.85(t, J=7.9 \mathrm{~Hz}, 1 \mathrm{H}), 6.09-6.07$ $(t, J=5.6 \mathrm{~Hz}, 1 \mathrm{H}), 3.50-3.46(m, 24 \mathrm{H}), 3.46-3.44(m, 2 \mathrm{H}), 3.43-3.41(m, 2 \mathrm{H}), 3.38-3.36(t, J=6.6 \mathrm{~Hz}$, $2 \mathrm{H}), 3.23(\mathrm{~s}, 3 \mathrm{H}), 3.08-3.04(q, J=12.8,6.8 \mathrm{~Hz}, 2 \mathrm{H}), 1.50-1.46(m, 2 \mathrm{H}), 1.42-1.40(m, 2 \mathrm{H}), 1.27(m, 8 \mathrm{H})$. ${ }^{13} \mathrm{C}$ NMR (DMSO- $d_{6}, 126 \mathrm{MHz}$ ) $\delta 155.22,140.60,128.63,120.92,117.57,71.30,70.33,69.81,69.60,69.50$, $58.07,39.25,29.76,29.22,28.88,28.79,26.36,25.64$. HRMS (ESI) Calcd. for $\mathrm{C}_{27} \mathrm{H}_{48} \mathrm{~N}_{2} \mathrm{NaO}_{8}[\mathrm{M}+\mathrm{Na}]^{+}$: $m / z$ 565.3465, Found: 565.3577. Anal. Calcd. for $\mathrm{C}_{28} \mathrm{H}_{50} \mathrm{~N}_{2} \mathrm{O}_{8}$ : C, 61.97; H, 9.29; N, 5.16, Found: C, 61.68; $\mathrm{H}, 9.43 ; \mathrm{N}, 5.04$.

\section{Conclusions}

To investigate the self-assembly behavior of UBD containing an amphiphilic chain in aqueous solution, three UBD (UBD-1-3) with different alkyl chain lengths, namely, hexyl, heptyl, and octyl, respectively, were prepared. All UBD formed identical spherical nanoparticles at concentrations above the CAC. Moreover, the size of the nanoparticles increased with increasing temperature because of the enhanced hydrophobic interactions due to dehydration of the ethylene glycol chains. In addition, the transmittance of the UBD solutions abruptly decreased, indicating an LCST behavior. A comparison of the CAC and LCST of the three UBD revealed that UBD-3 exhibited the smallest CAC and the largest LCST values, suggesting a relationship between the hydrophobicity of the UBD and its self-assembly behavior. Studies with varying concentrations of UBD (Figure 5, left scheme) revealed an equilibrium between the monomer and the nanoparticles. On the other hand, by varying the temperature (Figure 5, right scheme), the dehydration process was responsible for the formation of larger particles, which were in equilibrium with the nanoparticles. In the future, we plan to synthesize nanoparticles having functional groups for bioimaging [30] and investigate the self-assembly behavior of nanoparticles bearing different numbers of amphiphilic side chains.

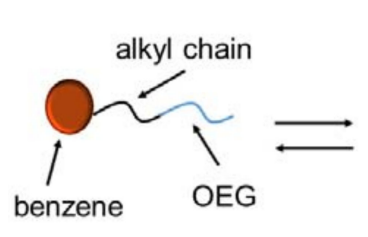

monomers

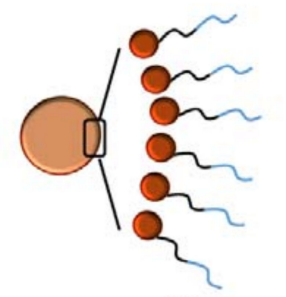

nanoparticles

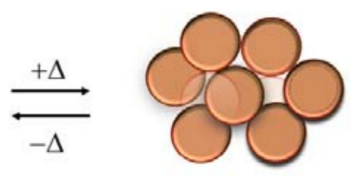

dehydrated particles

Figure 5. Predicted mechanism of the self-assembly of UBD in aqueous solution. 
Supplementary Materials: The following are available online at http:/ / www.mdpi.com/2076-3417/8/7/1080/s1, Concentration dependence of the ${ }^{1} \mathrm{H}$ NMR spectra of UBD-2 and -3. Temperature dependence of the $D_{\mathrm{H}}$ values and transmittance changes for UBD-1. Temperature dependence of the LCST behavior of UBD-2 and -3. FTIR spectra of the freeze-dry samples of UBD-1, -2, and -3.

Author Contributions: S.K. designed the experiments, conceived and supervised the project, analyzed the final data, and wrote the manuscript. Y.O., K.M., Y.F., and S.K. performed the experiments and analyzed the data to investigate the properties and mechanistic behavior of the materials. Y.F. checked the data and the manuscript, and discussed the results with the corresponding author.

Funding: This research received no external funding.

Acknowledgments: The authors thank Noboru Koga for the helpful discussions. This work was partially supported by the PRESTO Program on Molecular Technology from the Japan Science Technology Agency (JST).

Conflicts of Interest: The authors declare no conflict of interest.

\section{References}

1. Moro, T.; Takatori, Y.; Ishihara, K.; Konno, T.; Takigawa, Y.; Matsushiba, T.; Chung, U.I.; Nakamura, K.; Kawaguchi, H. Surface grafting of artificial joints with a biocompatible polymer for preventing periprosthetic osteolysis. Nat. Mater. 2004, 3, 829-836. [CrossRef] [PubMed]

2. Aoki, D.; Ajiro, D. Design of Polyurethane Composed of Only Hard Main Chain with Oligo(ethylene glycol) Units as Side Chain Simultaneously Achieved High Biocompatible and Mechanical Properties. Macromolecules 2017, 50, 6529-6538. [CrossRef]

3. Fujiyabu, T.; Li, X.; Shibayama, M.; Chung, U.; Sakai, T. Permeation of Water through Hydrogels with Controlled Network Structure. Macromolecules 2017, 50, 9411-9416. [CrossRef]

4. Allen, T.M.; Cullis, P.R. Drug delivery systems: Entering the mainstream. Science 2004, 303, $1818-1822$. [CrossRef] [PubMed]

5. Park, K.; Lee, S.; Kang, E.; Kim, K.; Choi, K.; Kwon, I.C. New Generation of Multifunctional Nanoparticles for Cancer Imaging and Therapy. Adv. Funct. Mater. 2009, 19, 1553-1566. [CrossRef]

6. Matsumura, Y.; Maeda, H. A new concept for macromolecular therapeutics in cancer chemotherapy: Mechanism of tumoritropic accumulation of proteins and the antitumor agent smancs. Cancer Res. 1986, 46, 6387-6392. [PubMed]

7. Maeda, H.; Wu, J.; Sawa, T.; Matsumura, Y.; Hori, K. Tumor vascular permeability and the EPR effect in macromolecular therapeutics: A review. J. Control. Release 2000, 65, 271-284. [CrossRef]

8. Jain, R.K. Transport of molecules across tumor vasculature. Cancer Metastasis Rev. 1987, 6, 559-593. [CrossRef] [PubMed]

9. Fox, M.E.; Szoka, F.C.; Fréchet, J.M.J. Soluble Polymer Carriers for the Treatment of Cancer: The Importance of Molecular Architecture. Acc. Chem. Res. 2009, 42, 1141-1151. [CrossRef] [PubMed]

10. Tannock, I.F.; Rotin, D. Acid pH in tumors and its potential for therapeutic exploitation. Cancer Res. 1989, 49, 4373-4384. [PubMed]

11. Li, Q.; Dunn, E.T.; Grandmaison, E.W.; Goosen, M.F.A. Applications and properties of chitosan. J. Bioact. Compat. Polym. 1992, 7, 370-397. [CrossRef]

12. Hayashi, H.; Ohkubo, K.; Karasawa, S.; Koga, N. Assemblies of Functional Small-Sized Molecules Having 4-Amio-2,2,6,6-tetramethylpiperidine-1-oxyl Responsive to Heat and $\mathrm{pH}$ in Water and Their Water Proton Relaxivities. Langmuir 2011, 27, 12709-12719. [CrossRef] [PubMed]

13. Morishita, K.; Murayama, S.; Araki, T.; Aoki, I.; Karasawa, S. Thermal- and pH-Dependent Size Variable Radical Nanoparticles and Its Water Proton Relaxivity for Metal-Free MRI Functional Contrast Agents. J. Org. Chem. 2016, 81, 8351-8362. [CrossRef] [PubMed]

14. Abe, Y.; Karasawa, S.; Koga, N. Crystal Structures and Emitting Properties of Trifluoromethylaminoquinoline Derivatives: Thermal Single-Crystal-to-Single-Crystal Transformation of Polymorphic Crystals That Emit Different Colors. Chem. Eur. J. 2012, 18, 15038-15048. [CrossRef] [PubMed]

15. Karasawa, S.; Todo, J.; Usui, K.; Harada, N.; Yoza, K.; Suemune, H.; Koga, N. Regioselective Photocyclizations of Di(quinolinyl)arylamines and Tri(quinolinyl)amine with Emission Color Changes and Photoreaction-induced Self-assemblies. Chem. Eur. J. 2016, 22, 7771-7781. [CrossRef] [PubMed] 
16. Karasawa, S.; Hagihara, R.; Abe, Y.; Harada, N.; Todo, J.; Koga, N. Structures, Thermal Properties, and Emission Behaviors of N,N-R-Phenyl-7-amino-2,4-trifluoromethylquinoline Derivatives: Supercooled Liquid-to-Crystal Transformation Induced by Mechanical Stimuli. Cryst. Growth Des. 2014, 14, 2468-2478. [CrossRef]

17. Harada, N.; Abe, Y.; Karasawa, S.; Koga, N. Polymorphic Equilibrium Responsive Thermal and Mechanical Stimuli in Light-emitting Crystals of N-Methylaminonaphthyridine. Org. Lett. 2012, 14, $6282-6285$. [CrossRef] [PubMed]

18. Hagihara, R.; Usui, K.; Karasawa, S. Two-step transformation of $p$-anisolylaminoquinoline derivatives induced by conformation- and packing-dominated processes. Dyes Pigments 2017, 143, 401-408. [CrossRef]

19. Araki, T.; Murayama, S.; Usui, K.; Shimada, T.; Aoki, I.; Karasawa, S. Self-Assembly Behavior of Emissive Urea Benzene Derivatives Enables Heat-Induced Accumulation in Tumor Tissue. Nano Lett. 2017, 17, 2397-2403. [CrossRef] [PubMed]

20. Allampally, N.A.; Florian, A.; Mayoral, M.A.; Rest, C.; Stepanenko, V.; Fernández, G. H-Aggregates of Oligophenyleneethynylene (OPE)-BODIPY Systems in Water: Guest Size-Dependent Encapsulation Mechanism and Co-aggregate Morphology. Chem. Eur. J. 2014, 20, 10669-10678. [CrossRef] [PubMed]

21. Rödle, A.; Lambov, M.; Mück-Lichtenfeld, C.; Stepanenko, V.; Fernández, G. Cooperative nanoparticle H-type self-assembly of a bolaamphiphilic BODIPY derivative in aqueous medium. Polymer 2017, 128, 317-324. [CrossRef]

22. Fielding, L.A.; Lane, J.A.; Derry, M.J.; Mykhaylyk, O.O.; Armes, S.P. Thermo-responsive Diblock Copolymer Worm Gels in Non-polar Solvents. J. Am. Chem. Soc. 2014, 136, 5790-5798. [CrossRef] [PubMed]

23. Mousseau, J.J.; Xing, L.; Tang, N.; Cuccia, L.A. Design and synthesis of urea-linked aromatic oligomers-A route towards convoluted foldamers. Chem. Eur. J. 2009, 15, 10030-10038. [CrossRef] [PubMed]

24. Aroua, S.; Gabrielle, E.; Tiu, V.; Ishikawa, T.; Yamakoshi, Y. Well-Defined Amphiphilic C60-PEG Conjugates: Water-Soluble and Thermoresponsive Materials. Helv. Chim. Acta 2016, 99, 805-813. [CrossRef]

25. Matsuura, H.; Miyazawa, T. Vibrational Analysis of Molten Poly(ethylene glycol). J. Polym. Sci. 1969, 7 , 1735-1769. [CrossRef]

26. Zhang, H.; Guo, S.; Fan, W. Zhao, Y. Ultrasensitive pH-Induced Water Solubility Switch Using UCST Polymers. Macromolecules 2016, 49, 1424-1433. [CrossRef]

27. Zhang, Q.; Weber, C.; Schubert, U.S. Hoogenboom, R. Thermoresponsive Polymers with Llower Critical Solution Temperature: From Fundamental Aspects and Measuring Techniques to Recommended Turbidimetry Conditions. Mater. Horiz. 2017, 4, 109-116. [CrossRef]

28. Mihajlovic, M.; Wyss, H.M.; Sijbesma, R.P. Effects of Surfactant and Urea on Dynamics and Viscoelastic Properties of Hydrophobically Assembled Supramolecular Hydrogel. Macromolecules 2018. [CrossRef]

29. Besson, E.; Mehdi, A.; Reyé, C.; Gaveau, P.; Corriu, R.J.P. Self-assembly of layered organosilicas based on weak intermolecular interactions. Dalton Trans. 2010, 39, 7534-7539. [CrossRef] [PubMed]

30. Morishita, K.; Okamoto, Y.; Murayama, S.; Usui, K.; Aoki, I.; Hirai, G.; Karasawa, S. Water-Proton Relaxivities of Radical Nanoparticles Self-Assembled via Hydration or Dehydration Processes. Langmuir 2017, 33, 7810-7817. [CrossRef] [PubMed]

(c) 2018 by the authors. Licensee MDPI, Basel, Switzerland. This article is an open access article distributed under the terms and conditions of the Creative Commons Attribution (CC BY) license (http://creativecommons.org/licenses/by/4.0/). 